\title{
ア行音発音時における口唇と上下顎前霜との関係
}

\author{
九州歯科大学歯科補綴学第 1 講座（指導: 豊田静夫教授）
}

$$
\text { 三井隆文 }
$$

昭和63年 2 月19日受付

\section{Relations Between the Lips and the Upper and Lower Anterior Teeth at Pronounciation of Five Vowels}

Takafumi Mi-i

First Department of Prosthetic Dentistry (Director: Prof. Shizuo Toyoda) Kyushu Dental College, Kitakyushu, Japan

In prosthesis for the anterior teeth, care must be given to forming the maxillary lingual surface and positions of the mandibular incisal edges in harmony with jaw movement and to forming lengths of the maxillary anterior teeth and degree of overlap of the upper and lower anterior teeth not in interference with pronounciation. It is also necessary to consider esthetics for the anterior teeth.

Therefore, with a view to clarifying characteristics of the face at rest and at function, positional relations at rest between incisal edges of the maxillary anterior teeth and the conjugate of the lips were measured with 50 males in their twenties as subjects. Visibility of the upper and lower anterior teeth during pronounciation of five vowels was also examined.

The results were as follows:

1. When the lips were not tense at intercuspal position, the incisal edges of the upper central incisors were $2.0 \pm 1.6 \mathrm{~mm}$ below the conjugate of the lips. The incisal edge positions ranged from $5.8 \mathrm{~mm}$ below the conjugate of the lips to $2.2 \mathrm{~mm}$ above.

2. Clinical coronal lengths of the upper anterior teeth were $10.8 \pm 1.0 \mathrm{~mm}$ for the central incisors, $9.2 \pm 0.9 \mathrm{~mm}$ for the lateral incisors, and $10.2 \pm 1.1 \mathrm{~mm}$ for the canines. For the lower teeth, the lengths were $8.6 \pm 1.0 \mathrm{~mm}$ for the central incisors, $9.0 \pm 1.0 \mathrm{~mm}$ for the lateral incisors, and $10.5 \pm 1.2 \mathrm{~mm}$ for the canines.

3. The lengths of the upper anterior teeth exposed at pronounciation of five vowels were $\mathrm{i}>\mathrm{e} \fallingdotseq \mathrm{a}>\mathrm{u}>\mathrm{o}$ for the central and lateral incisors, and $\mathrm{i}>\mathrm{e} \fallingdotseq \mathbf{a}>\mathrm{u}=\mathrm{o}$ for the canines. For the lower jaw, the lengths were $i>e>a>u>0$ for all the teeth.

4. The ratios of vertical lengths of the upper anterior teeth exposed at pronounciation of five vowels were $\underline{1}: \underline{2}: \underline{3}=1: 0.4: 0.2$ for ' $a$ ', $1: 0.7: 0.3$ for ' $i$ ', $1: 0.1: 0.0$ for ' $u$ ', $1: 0.5: 0.2$ for ' $e$ ', and $1: 0.0: 0.0$ for ' 0 '.

5 . The ratios of vertical lengths of the lower anterior teeth exposed at pronounciation of five vowels were $\overline{1}: \overline{2}: \overline{3}=1: 1.0: 0.9$ for ' $a$ ', ' $\mathrm{i}$ ', 'e', $1: 0.5: 0.1$ for ' $\mathrm{u}$ ', and 
$1: 0.6: 0.0$ for ' $o$ '.

6. The clinical surface areas of the upper jaws projected on the coronal plane were $79.4 \pm 9.8 \mathrm{~mm}^{2}$ for the central incisors, $47.6 \pm 6.4 \mathrm{~mm}^{2}$ for the lateral incisors, and $43.4 \pm$ $6.9 \mathrm{~mm}^{2}$ for the canines. For the lower jaws, they were $38.2 \pm 5.7 \mathrm{~mm}^{2}$ for the central incisors, $40.0 \pm 5.7 \mathrm{~mm}^{2}$ for the lateral incisors, and $42.6 \pm 6.9 \mathrm{~mm}^{2}$ for the canines.

7. The ratios of surface areas of the upper anterior teeth exposed at pronounciation of five vowels were $\underline{1}: \underline{2}: \underline{3}=1: 0.2: 0.1$ for ' $a$ ', $1: 0.4: 0.1$ for ' $i$ ', $1: 0.0: 0.0$ for ' $u$ ', $1: 0.3: 0.1$ for ' $\mathrm{e}$ ', and $1: 0.0: 0.0$ for ' 0 '.

8. The ratios of surface areas of the lower anterior teeth exposed at pronounciation of five vowels were $\overline{1}: \overline{2}: \overline{3}=1: 0.9: 0.6$ for ' $a$ ', $1: 1.0: 0.8$ for ' $i$ ', $1: 0.4: 0.0$ for ' $u$ ', $1: 0.9: 0.6$ for ' $\mathrm{e}$ ', and $1: 0.5: 0.0$ for ' 0 '.

Key words: Lip/Upper and lower anterior teeth/Pronounciation of five vowels/ Clinical coronal length/Esthetics

緒 言

咀嚼機能が十分に発撣でき，発音上全く支障がない補 綴物であっても，審美的考慮がなされていなければ，患 者の満足を得ることはできない，審美は概念的なもので あるために，その評価は時代とともに変化してきたし， 生活場所あるいは生活環境によっても異なるが，審美的 満足度に対しては，乙れらの要因とともに個人の感覚が 大きく影響を及ぼす。そこで，前㐘部を含む補綴を行う にあたっては，特殊な場合を除いて，健全な状態で存在 していた天然歯とほぼ同じうに回復するてとが基本で あるとの考光が一般的である ${ }^{1,2)}$.

審美に関しては，人工雨列を自然感あふれるものにす るための方法を，Williams $(1911 ， 1914)^{3,4}$, Stein (1936) ${ }^{51}$ などが古くから報告しているが，乙れらを体系 づけ，補経臨床への導入に功績があったのは，Frush と Fisher $(1955 \sim 1958)^{6-10)}$ であろう. 彼らは性的要 因，性格的要因，年秢的要因を考慮した裙経物を作製す ることの必要性を主張した。

わが国においても，日本人の顔面あるいは歯列の形態

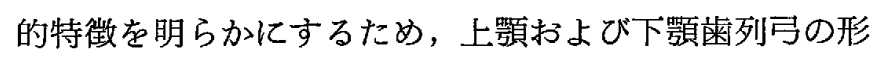
態的特徵 ${ }^{11-13)}$, 上下顎前歯の臨床的形態 14-17), 上顎 前霜と口唇との位置的関係 ${ }^{18,19)}$, 顔面の形態と中切菌 あるいは雬列弓形態との類似性 20-22)などについて多く の研究者が検討してきた。さらに年齢的要因をも含めた 検討を，松本 $(1965)^{23)}$ ，佐藤 $(1981)^{24)}$, 佐藤 (1987) $25)$ らが，また色彩学的検討を Sproull $(1973)^{261}$, 河 辺 $(1959)^{27-291}$, 土屋 $(1973)^{301}$, 上原 $(1981)^{31}$ ら
が行っている.乙れらは, 崡牙あるいは歯列を再構成す るための基礎となる憲美関する静的観察の範疇にいれ ることができよう。

歯は口腔内の所定の位置にあって, 動くことはない が，それに近接して存在する口唇が機能に応じて動くて とにより，歯の見え具合いが異なるため，顔面美に与え る影響は極めて大きい.したがって, 機能時において自 然感のある蒾列を作ることが必要である。乙れは動態番 美といわれており，Matthews (1978) ${ }^{32) ， A n t h o n y ~}$ ら (1984 $)^{331}$, 木村ら $(1985)^{34)}$ らは, 顔面表情の代表 として微笑を取り上げて検討した。しかし，発音時の検 討はほとんどなされて扔らず, Pound $(1966,1976)^{35}$, 36), 山縣 $(1976,1982)^{37}, 38$ らが発音に支障がないよ うな前歯の排列位置決定法ならびに確認法について報告 しているにすぎない。

そこで, 著者は, 発音時に顔面と調和した前䨑部歯列 弓の形態的特徵を明らかにするために，ア行音発音時の 雨の見元具合いについて成年男子を対象にして検討し， 興味ある知見を得たので報告する。

\section{研究試料および研究方法}

\section{I . 被験者の選択基準}

本研究では，いわゆる個性正常咬合を有し，発音が正 常と思われる20歳代の男性50名を被験者とした。被験者 の選択にあたっては，堀(1979) ${ }^{391}$ ，佐藤 (1981) 24'，佐 藤 (1987) 252 の基準を参考にして, 以下の項目に従った。

1. 全身状態が良好で, 䕱関節, 咀嚼筋群に現症, 既 往症がないもの. 
2. 視診, 触診により, 歯周組織が健全なもの.

3. 先天性欠如歯, 未萌出歯, 欠損雬, 奇形雬, 過剩 菌がないもの.

4. 歯が著しく捻転, 転位, 傾斜していないもの.

5. 咬頭嵌合位が明確なもの.

6. 開咬, 切端咬合, 過蓋咬合, 反対咬合, 正中離開 がないもの.

7. 矯正治療の既往歴がないもの.

8. 顔面正中線に対して, 左右中切茵の接触点が大き く左右に偏位していないもの.

II . 研究方法

A. 計測用試料の作製法

1. 顔面計測法

被験者の頭部を, フランクフルト平面が床面と平行に なるように頭部固定装置で固定し，静かに口を閉じさせ て咬頭嵌合位を保たせ，口唇が緊張していないときの上 下口唇接合線の位置を上顎左側中切歯唇面に印記した。 な押, 上顎左側中切歯切縁の方が上下口辰接合線より上 にある場合には，上下口唇接合線は下䫇中切菌唇面に印 記した。

\section{2. 計測用写真の撮影法}

顔面計測法と同しく，フランクフルト平面が床面と平 行になるように頭部固定装置で頭部を固定し， $105 \mathrm{~mm}$ レンズ付きニコン社製カメラにより，つぎの状態に打け る顔面下半分の写真を正面から撮影した。このとき人工 光を用いると不必要な部分に口唇の影ができるため, 自 然光下で撮影するととにした。なお，フィルムは感度が 良好な ASA 400 を用いた。

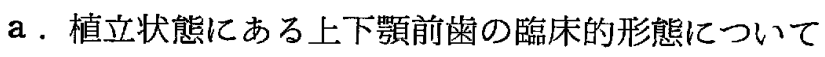
上顎前崡が下顎前雨を被蓋しない程度にわずかに開口 させ，上下顎前雬の歯頸部が完全に露出するまで口唇鈎 で口唇を率引儿た状態。

b. 発音時の顔面写真について

被験者にア行音の各音を長めに発音させて, 口唇の動 きが安定し，比較的動かなくなったときの状態.

B. 計測項目おるび検討方法

上下口唇接合線に対する上顎左側中切歯切縁の位置に 関する計測は直接顔面上で, 植立状態にある上下顎前菌 歯冠の垂直的最大長径扔よびア行音発音時に露出した上 下顎前歯の垂直的長さに関する計測は，拡大プリントし た計測用写真上で，ミットヨ製 $1 / 20 \mathrm{~mm}$ 副尺付ノギスで 行った。また，ア行音発音時に露出した上下顎各前㐘の 表面積および植立状態にある上下顎前茵の表面積につい ては KONTORON 社製画像解析装置 MOP 20 で計測
した．その後, 拡大プリントした写真上で得られた計測 值は，拡大率で除して実測值を算出した。な抢表面積は 顔面の正面写真で計測したので, 前頭面投影蔝冠表面積 とよぶべきであるが，以後萰冠表面積と略す.

1. 上下口唇接合線に対する上顎左側中切歯の位置に つい

咬頭嵌合位において，口唇が緊張していないときの上 下口唇接合線の位置を描記した線と, 上顎左側中切茵切 縁の位置との垂直的距離をるットヨ製 $1 / 20 \mathrm{~mm}$ 副尺付 ギスで計測した。

2. 植立状龍にある上下顎前雨菌冠の大きさについて a 、上顎各前歯の垂直的長さ

上顎各前茵の切縁中央部最下点から歯頸部最深点まで の垂直的最大長とした. 以下てれを上顎前歯の臨床的歯 冠長という.

b . 下顎各前歯の垂直的長さ

下顎各前雪の切縁中央部最上点から歯頸部最深点まで の垂直的最大長とした．以下とれを下顎前崡の臨床的歯 冠長という.

\section{c . 上顎各前歯の表面積}

上頡各前茵の切縁下端, 歯頸線, 歯冠隣接面外形線で 团まれた範囲とした．以下てれを上㖽前菊の臨床的苗冠 表面積という。

\section{d. 下頜各前歯の表面積}

下箩各前歯の切縁上端, 歯頸線, 歯冠隣接面外形線で

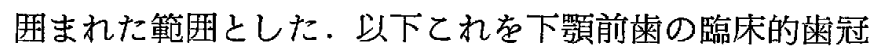
表面積という。

3.ア行音発音時に露出した上下顎各前䨑の垂直的長 き

a . 露出した上顎各前歯の垂直的長さ

ア行音発音時における上唇下端より上顎各前歯の切縁 中央部最下点までの垂直的最大長とした。

b . 露出した下顎各前曾の垂直的長さ

ア行音発音時における下唇上端より下顎各前歯の切縁 中央部最上点までの垂直的最大長とした。

c. 露出した上顎各前歯の表面積

ア行音発音時に上唇下端および各茵冠の切縁，隣接面 外形で囲まれた範囲とした。

d. 露出した下䫇各前歯の表面積

ア行音発音時に下唇上端および各歯冠の切縁, 隣接面 外形で围まれた範囲とした。

てれらの計测值から，以下の項目について検討した。

1. 安静時における上下口唇接合線と上顎左側中切歯 切縁との上下的位置関係 
2. 上額の臨床的歯冠長に対するア行音発音時に露出 した上顎同名歯の垂面的長さの比

3. 下額の臨床的歯冠長に対するア行音発音時に露出 した下顎同名歯の垂直的長さの比

4. ア行音発音時に露出した上額前蒾の垂直的長さに 関する粜牙間の比

5. ア行音発音時に露出した下額前歯の垂直的長さに 関する歯牙間の比

6. ア行音発音時に露出した上顎前雬の垂直的長さに 対する下額同名歯の垂直的長さの比

7. 上顎各前柬の臨床的表面積に対するア行音発音時 に露出した上䖀同名歯の表面積の比

8. 下顎各前歯の臨床的表面積に対するア行音発音時 に露出した下顎同名歯の表面積の比

9.ア行音発音時に露出した上顎前雬の表面積に関す る雬牙間の比

10.ア行音発音時に露出した下顎前歯の表面積に関す る歯牙間の比

11.ア行音発音時に露出した上顎前㐘表面積に対する 下䫈同名前歯表面積の比

\section{研 究 結 果}

1. 安静時に抢ける上下口唇接合線と上顎左側中切歯 切縁との上下的位置関係

上顎左側中切歯が上下口唇接合線より下にある場合を 十，上にある場合をーとして両者の位置的関係を計測し たところ，最大值は $+5.8 \mathrm{~mm}$ ，最小值はー $2.2 \mathrm{~mm}$ であ

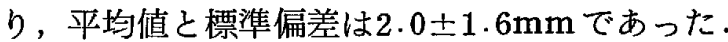

このとき，上顎左側中切畨切縁が上下口唇接合線より 下にあったものは 43 例 $(86 \%)$ ，上にあったものは 2 例 (4\%)，ほほ同じ高さにあったものは 5 例（10\%）であ った.

2. 上下顎前歯の臨床的歯冠長

各前匊の切縁中央部から歯頸部最深点までの垂直的最 大長径を計測し，左右同名䨑の平均值として表示した (表 1 ).

上顎中切茵の臨床的柬冠長は $10.8 \pm 1.0 \mathrm{~mm}$, 側切歯 表 1 上下顎前歯の臨床的菌冠長

\begin{tabular}{lr|r|r|l}
\hline \hline & & 中 切 歯 & 側 切 歯 & 犬 \\
\hline 上 & 顎 & $10.8 \pm 1.0$ & $9.2 \pm 0.9$ & $10.2 \pm 1.1$ \\
\hline 下 & 顎 & $8.6 \pm 1.0$ & $9.0 \pm 1.0$ & $10.5 \pm 1.2$ \\
\hline
\end{tabular}

(単位 $: \mathrm{mm}$ )

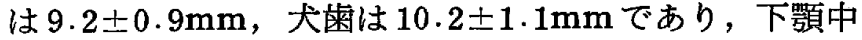
切歯は $8.6 \pm 1.0 \mathrm{~mm}$, 側切歯は $9.0 \pm 1.0 \mathrm{~mm}$, 犬菌は $10.5 \pm 1.2 \mathrm{~mm}$ であった.

3. ア行音発音時に露出した上下顎前菌の垂直的長さ ア行音発音時に露出した上顎前菊の垂直的長さは，上

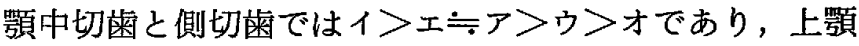
犬蒾ではイ>エうア>ウ＝オであった（表 2 ）。上額前 雪が露出しなかった割合は，ウとオが最も高く，次いで ェとアで，イが最も低かったままたすべての被験者で露 出したのは，イ発音時の中切歯だけであった．側切歯お よび犬雨においては, ウでそれぞれ $92,100 \%$, オでそ れぞれ98，100\%とほとんどの被験者で露出していなか った (表 3 ).

ここで，咬頭嵌合位における上下口唇接合線に対する 上顎中切柬切緣の位置関係と, ア行音発音時に露出した 上顎中切歯の垂直的長さの相関関係を求めたところ, $\mathrm{r}=0.69$ で高度に有意であり, 回帰直線は $\mathrm{y}=0.1 \mathrm{x}+$ 1.87であった。

下顎前歯に执いて，ア行音発音時に露出した重直的長 さは, 中切匊, 側切菡, 犬蒾ともイ>エ>ア>ウ>オの 順であった（表 4）。下顎前函が露出しなかった割合は, ア行音発音時に露出した垂直的長さの順序とは逆で, 才 が最も高く，次いでウ，ア，エ，イの順であった．全て

表 2 ア行音発音時に露出した上顎前蒾の垂直的 長さ

\begin{tabular}{c|c|c|c}
\hline & $\underline{1}$ & $\underline{2}$ & $\underline{3}$ \\
\hline$ア$ & $3.8 \pm 2.3$ & $1.7 \pm 1.9$ & $0.6 \pm 1.4$ \\
イ & $5.3 \pm 2.5$ & $3.5 \pm 2.1$ & $1.8 \pm 2.3$ \\
ウ & $1.5 \pm 1.6$ & $0.1 \pm 0.5$ & $0.0 \pm 0.0$ \\
エ & $3.8 \pm 2.4$ & $2.0 \pm 2.1$ & $0.7 \pm 1.7$ \\
オ & $0.9 \pm 1.5$ & $0.0 \pm 0.3$ & $0.0 \pm 0.0$ \\
\hline
\end{tabular}

(単位：mm)

表 3 ア行音発音時に露出しなかった上顎前歯の 比率

\begin{tabular}{l|r|r|r}
\hline \hline & 1 & $\underline{2}$ & $\underline{3}$ \\
\hline$ア$ & 4 & 29 & 80 \\
$イ$ & 0 & 2 & 47 \\
$ウ$ & 41 & 92 & 100 \\
$エ$ & 8 & 22 & 78 \\
オ & 57 & 98 & 100 \\
\hline
\end{tabular}

(単位：\%) 
の被験者で露出したのはイ発音時の中切䨑, 側切歯, 犬

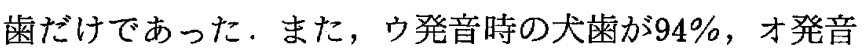
時の中切歯が $82 \%$ ，側切歯が $84 \%$ ，犬歯が $98 \%$ と高い割 合で露出していなかった（表 5 ).

表 4 ア行音発音時に露出した下䫈前歯の垂直的 長さ

\begin{tabular}{c|c|c|c}
\hline \hline & $\overline{1}$ & $\overline{2}$ & $\overline{3}$ \\
\hline$ア$ & $2.6 \pm 2.0$ & $2.6 \pm 2.2$ & $2.3 \pm 2.1$ \\
イ & $5.9 \pm 2.0$ & $5.9 \pm 1.9$ & $5.4 \pm 2.0$ \\
ウ & $1.9 \pm 2.1$ & $1.0 \pm 1.4$ & $0.1 \pm 0.3$ \\
エ & $3.6 \pm 2.3$ & $3.5 \pm 2.4$ & $3.1 \pm 2.2$ \\
オ & $0.5 \pm 1.1$ & $0.3 \pm 0.7$ & $0.0 \pm 0.1$ \\
\hline
\end{tabular}

(単位 $: \mathrm{mm}$ )

表 5 ア行音発音時に露出しなかった下顎前雬の 比率

\begin{tabular}{c|r|r|r}
\hline & $\overline{1}$ & $\overline{2}$ & $\overline{3}$ \\
\hline ア & 16 & 18 & 27 \\
イ & 0 & 0 & 0 \\
ウ & 35 & 55 & 94 \\
エ & 8 & 10 & 16 \\
オ & 82 & 84 & 98 \\
\hline
\end{tabular}

(単位:\%)

4. 臨床的歯冠長に対するア行音発音時に露出した雬 の垂直的長さの比

各歯牙の臨床的歯冠長を 1 として, てれに対するア行 音発音時に露出した部分の垂直的長さの比の平均値と標 準偏差を求めた（表 6,7 ）.

上顎中切歯, 側切䨑, 犬歯ではそれぞれ，アで $0.4 \pm$ $0.2,0.2 \pm 0.2,0.1 \pm 0.1$, イで $0.5 \pm 0.2,0.4 \pm 0.2$, $0.2 \pm 0.2$, ウで $0.1 \pm 0.2,0.0 \pm 0.1,0.0 \pm 0.0$, エで

表 6 臨床的歯冠長に対するア行音発音時に露出し た上顎前歯の垂直的長さの比

\begin{tabular}{c|c|c|c}
\hline & 1 & 2 & $\underline{3}$ \\
\hline$ア$ & $0.4 \pm 0.2$ & $0.2 \pm 0.2$ & $0.1 \pm 0.1$ \\
イ & $0.5 \pm 0.2$ & $0.4 \pm 0.2$ & $0.2 \pm 0.2$ \\
ウ & $0.1 \pm 0.2$ & $0.0 \pm 0.1$ & $0.0 \pm 0.0$ \\
エ & $0.4 \pm 0.2$ & $0.2 \pm 0.2$ & $0.1 \pm 0.2$ \\
オ & $0.1 \pm 0.1$ & $0.0 \pm 0.0$ & $0.0 \pm 0.0$ \\
\hline
\end{tabular}

$0.4 \pm 0.2,0.2 \pm 0.2,0.1 \pm 0.2$, オで $0.1 \pm 0.1,0.0 \pm$ $0.0,0.0 \pm 0.0$ であった（表 6 ).

下顎に扔いてはそれぞれアで $0.3 \pm 0.2 ， 0.3 \pm 0.3$ ， $0.2 \pm 0.2$, イで $0.7 \pm 0.2,0.7 \pm 0.2,0.5 \pm 0.2$, ウで $0.2 \pm 0.2,0.1 \pm 0.2,0.0 \pm 0.0$, エで $0.4 \pm 0.3,0.4 \pm$ $0.3,0.3 \pm 0.2$, オで $0.1 \pm 0.1,0.0 \pm 0.1,0.0 \pm 0.0 て ゙$ あった（表 7 ).

表 7 臨床的歯冠長に対するア行音発音時に露出し た下堮前齿の垂直的長さの比

\begin{tabular}{c|c|c|c}
\hline \hline & $\overline{1}$ & $\overline{2}$ & $\overline{3}$ \\
\hline$ア$ & $0.3 \pm 0.2$ & $0.3 \pm 0.3$ & $0.2 \pm 0.2$ \\
イ & $0.7 \pm 0.2$ & $0.7 \pm 0.2$ & $0.5 \pm 0.2$ \\
ウ & $0.2 \pm 0.2$ & $0.1 \pm 0.2$ & $0.0 \pm 0.0$ \\
エ & $0.4 \pm 0.3$ & $0.4 \pm 0.3$ & $0.3 \pm 0.2$ \\
オ & $0.1 \pm 0.1$ & $0.0 \pm 0.1$ & $0.0 \pm 0.0$ \\
\hline
\end{tabular}

5.ア行音発音時に露出した上頻前蒾および下顎前歯 の垂直的長さに関する歯牙間の比

ア行音発音時に露出した上顎前蒾の垂直的長さの平均 值と標準偏差は, 中切粜，側切歯，犬歯でそれぞれ，ア で $3.8 \pm 2.3 \mathrm{~mm}, 1.7 \pm 1.9 \mathrm{~mm}, 0.6 \pm 1.4 \mathrm{~mm}$, イで 5.3 $\pm 2.5 \mathrm{~mm}, 3.5 \pm 2.1 \mathrm{~mm}, 1.8 \pm 2.3 \mathrm{~mm}$, ウで $1.5 \pm 1.6$ $\mathrm{mm}, 0.1 \pm 0.5 \mathrm{~mm}, 0.0 \pm 0.0 \mathrm{~mm}$, エで3.8 $\pm 2.4 \mathrm{~mm}$, $2.0 \pm 2.1 \mathrm{~mm}, 0.7 \pm 1.7 \mathrm{~mm}$ ，オで $0.9 \pm 1.5 \mathrm{~mm}, 0.0$ $\pm 0.3 \mathrm{~mm}, 0.0 \pm 0.0 \mathrm{~mm}$ であった（表 2 ).

ア行音発音時の上顎中切兩の露出度を 1 として, 側切 歯, 犬歯の比率を求めた。アでは $1: \underline{2}: \underline{3}=1: 0.4$ $: 0.2$, イでは $1: 0.7: 0.3$, ウでは $1: 0.1: 0.0$, エ

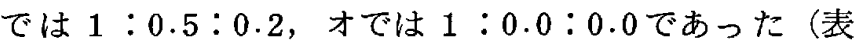
$8)$.

また，ア行音発音時に露出した下顎前歯の垂直的長さ の平均值と標準偏差は, 中切歯, 側切歯, 犬歯でそれぞ れ, アで $2.6 \pm 2.0 \mathrm{~mm}, 2.6 \pm 2.2 \mathrm{~mm}, 2.3 \pm 2.1 \mathrm{~mm}$,

表 8 ア行音発音時に露出した上顎前歯の垂直的長 さに関する歯牙間の比

\begin{tabular}{c|rrrrr}
\hline \hline & $\underline{1}$ & $:$ & $\underline{2}$ & $:$ & $\underline{3}$ \\
\hline ア & 1 & $:$ & 0.4 & $:$ & 0.2 \\
イ & 1 & $:$ & 0.7 & $:$ & 0.3 \\
ウ & 1 & $:$ & 0.1 & $:$ & 0.0 \\
エ & 1 & $:$ & 0.5 & $:$ & 0.2 \\
オ & 1 & $:$ & 0.0 & $:$ & 0.0
\end{tabular}


イで $5.9 \pm 2.0 \mathrm{~mm}, 5.9 \pm 1.9 \mathrm{~mm}, 5.4 \pm 2.0 \mathrm{~mm}$, ウで $1.9 \pm 2.1 \mathrm{~mm}, 1.0 \pm 1.4 \mathrm{~mm}, 0.1 \pm 0.3 \mathrm{~mm}$, エで $3.6 \pm$ $2.3 \mathrm{~mm}, 3.5 \pm 2.4 \mathrm{~mm}, 3.1 \pm 2.2 \mathrm{~mm}$ ，オで $0.5 \pm 1.1$ $\mathrm{mm}, 0.3 \pm 0.7 \mathrm{~mm}, 0.0 \pm 0.1 \mathrm{~mm}$ であった（表 4 ）.

ア行音発音時の下顎中切歯の露出度を 1 として側切 歯, 犬雪の比率を求めた.アでは $\overline{1}: \overline{2}: \overline{3}=1: 1.0$ :0.9, イでは $1: 1.0: 0.9$, ウでは $1: 0.5: 0.1$, エ

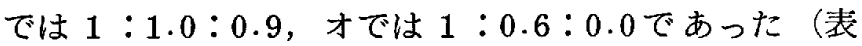
9).

表 9 ア行音発音時に露出した下顎前䨓の垂直的長 さに関する苗牙間の比

\begin{tabular}{c|ccccc}
\hline \hline & $\overline{1}$ & $:$ & $\overline{2}$ & $:$ & $\overline{3}$ \\
\hline ア & 1 & $:$ & 1.0 & $:$ & 0.9 \\
イ & 1 & $:$ & 1.0 & $:$ & 0.9 \\
ウ & 1 & $:$ & 0.5 & $:$ & 0.1 \\
エ & 1 & $:$ & 1.0 & $:$ & 0.9 \\
オ & 1 & $:$ & 0.6 & $:$ & 0.0 \\
\hline
\end{tabular}

6. ア行音発音時に露出した上顎前蒾に対する下顴同 名歯の垂直的長さに関する些牙間の比

上顎前歯の露出度を 1 として，乙れに対する下顎同名 雪の露出度を比較的単純な比として表した，アでは中切 歯が $1: 0.7$, 側切歯が $1: 1.5$, 犬雪が $1: 3.8$, イで は中切歯が $1: 1.1$, 側切歯が $1: 1.7$, 犬歯が 1 : 3.0 , ウでは中切雪が $1: 1.3$, 側切霆が $1: 10.0$, エで は中切霖が $1: 0.9$, 側切菌が $1: 1.8$, 犬歯が $1: 4.4$,

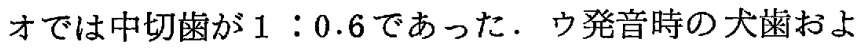
びオ発音時の側切歯, 犬柬は上下䫟ともほとんど露出し ていなかった（表10）.

表10ア行音発音時に露出した上顎前歯の垂直的長 さに対する下顎前蒾の垂直的長さの比

\begin{tabular}{|c|c|c|c|c|}
\hline & 中 切歯 & 側 切 㐘 & 犬 & 歯 \\
\hline $\mathcal{P}$ & $1: 0.7$ & $1: 1.5$ & 1 & $: 3.8$ \\
\hline 1 & $1: 1.1$ & $1: 1.7$ & 1 & $: 3.0$ \\
\hline ウ & $1: 1.3$ & $1: 10.0$ & 0 & $: 0.0$ \\
\hline$工$ & $1: 0.9$ & $1: 1.8$ & 1 & $: 4.4$ \\
\hline 才 & $1: 0.6$ & $0: 0.0$ & 0 & $: 0.0$ \\
\hline
\end{tabular}

\section{7. 上下顎前歯の臨床的雬冠表面積}

上顎 中切米の臨床的曾冠表面積は $79.4 \pm 9.8 \mathrm{~mm}^{2}$, 側切粜は $47.6 \pm 6.4 \mathrm{~mm}^{2}$, 大歯は $43.4 \pm 6.9 \mathrm{~mm}^{2}$ であ り, 下顎 中切歯は $38.2 \pm 5.7 \mathrm{~mm}^{2}$, 側切歯は $40.0 \pm 5.7$ $\mathrm{mm}^{2}$ ，犬蒾は $42.6 \pm 6.9 \mathrm{~mm}^{2}$ であった（表11）。

表11 上下㖽前歯の臨床的歯冠表面積

\begin{tabular}{lc|c|c|c}
\hline & & 中 切 霜 & 側 切 雪 & 犬 \\
\hline 上 & 顎 & $79.4 \pm 9.8$ & $47.6 \pm 6.4$ & $43.4 \pm 6.9$ \\
\hline 下 & 顎 & $38.2 \pm 5.7$ & $40.0 \pm 5.7$ & $42.6 \pm 6.9$ \\
\hline
\end{tabular}

(単位: $\mathrm{mm}^{2}$ )

8. ア行音発音時に露出した上下䪽前歯の表面積

ア行音発音時に露出した上䝷前歯の表面積の平均值と 䅺準偏差は，中切歯，側切歯，犬歯でそれぞれ，アで $28.1 \pm 18.0 \mathrm{~mm}^{2}, 6.1 \pm 8.6 \mathrm{~mm}^{2}, 1.5 \pm 3.7 \mathrm{~mm}^{2}$, イで $38.5 \pm 19.0 \mathrm{~mm}^{2}, 15.1 \pm 11.5 \mathrm{~mm}^{2}, 5.5 \pm 8.0 \mathrm{~mm}^{2}$, ウ で $9.0 \pm 10.6 \mathrm{~mm}^{2}, 0.3 \pm 1.6 \mathrm{~mm}^{2}, 0.0 \pm 0.0 \mathrm{~mm}^{2}$, 工

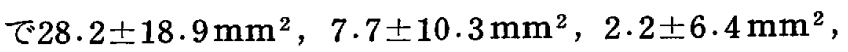

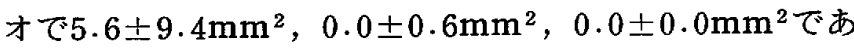
った (表12).

また，ア行音発音時に露出した下顎前粜の表面積の平 均值と標準偏差は, 中切歯, 側切歯, 犬歯でそれぞれ, アで12.5 $\pm 9.7 \mathrm{~mm}^{2}, 11.7 \pm 10.4 \mathrm{~mm}^{2}, 7.7 \pm 8.5 \mathrm{~mm}^{2}$, イで $27.7 \pm 9.2 \mathrm{~mm}^{2}, 27.5 \pm 9.2 \mathrm{~mm}^{2}, 21.6 \pm 9.4 \mathrm{~mm}^{2}$, ウで $8.8 \pm 9.4 \mathrm{~mm}^{2}, 3.2 \pm 5.1 \mathrm{~mm}^{2}, 0.1 \pm 0.4 \mathrm{~mm}^{2}$, I で $17.2 \pm 11.3 \mathrm{~mm}^{2}, 16.2 \pm 10.9 \mathrm{~mm}^{2}, 11.0 \pm 8.8 \mathrm{~mm}^{2}$ ， オで $1.9 \pm 4.7 \mathrm{~mm}^{2}, 0.9 \pm 2.7 \mathrm{~mm}^{2}, 0.0 \pm 0.3 \mathrm{~mm}^{2}$ で あった（表13）.

表12ア行音発音時に露出した上䫛前米の表面積

\begin{tabular}{l|r|r|c}
\hline \hline & \multicolumn{1}{|c|}{1} & \multicolumn{1}{c|}{2} & \multicolumn{1}{c}{3} \\
\hline$ア$ & $28.1 \pm 18.0$ & $6.1 \pm 8.6$ & $1.5 \pm 3.7$ \\
イ & $38.5 \pm 19.0$ & $15.1 \pm 11.5$ & $5.5 \pm 8.0$ \\
$ウ$ & $9.0 \pm 10.6$ & $0.3 \pm 1.6$ & $0.0 \pm 0.0$ \\
$エ$ & $28.2 \pm 18.9$ & $7.7 \pm 10.3$ & $2.2 \pm 6.4$ \\
オ & $5.6 \pm 9.4$ & $0.0 \pm 0.6$ & $0.0 \pm 0.0$ \\
\hline
\end{tabular}

(単位: $\mathrm{mm}^{2}$ )

表13 ア行音発音時に露出した下䋶前歯の表面積

\begin{tabular}{c|r|r|r}
\hline \hline & \multicolumn{1}{|c|}{$\overline{1}$} & \multicolumn{1}{c}{$\bar{c}$} \\
\hline ア & $12.5 \pm 9.7$ & $11.7 \pm 10.4$ & \multicolumn{1}{c}{$7.7 \pm 8.5$} \\
イ & $27.7 \pm 9.2$ & $27.5 \pm 9.2$ & $21.6 \pm 9.4$ \\
ウ & $8.8 \pm 9.4$ & $3.2 \pm 5.1$ & $0.1 \pm 0.4$ \\
エ & $17.2 \pm 11.3$ & $16.2 \pm 10.9$ & $11.0 \pm 8.8$ \\
オ & $1.9 \pm 4.7$ & $0.9 \pm 2.7$ & $0.0 \pm 0.3$ \\
\hline
\end{tabular}

(単位: $\mathrm{mm}^{2}$ ) 
9. 臨床的歯冠表面積に対するア行音発音時に露出し た歯の表面積の比

各上顎前茵の臨床的菌 冠表面積を 100 として，これに 対する露出部分の表面積の比の平均值と標準偏差を求め た. 中切歯, 側切歯, 犬歯でそれぞれ, アで35.1士21.4, $12.6 \pm 17.1,3.4 \pm 8.2$, イで $48.7 \pm 23.9,32.5 \pm 25.2$, $12.9 \pm 19.1$, ウで $11.2 \pm 12.8,0.7 \pm 3.1,0.0 \pm 0.0$, エ

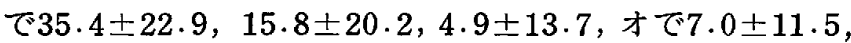
$0.0 \pm 1.2,0.0 \pm 0.0$ であった（表14）.

各下珻前歯の臨床的歯冠表面積を 100 として，これに 対するア行音発音時に露出した部分の表面積の比の平均 值と標準偏差を求めた．中切歯，側切歯，犬歯でそれぞ れ，アで $32.5 \pm 25.5,29.6 \pm 26.1,18.4 \pm 20.3$ ，イで $72.9 \pm 22.8,69.7 \pm 23.3,51.3 \pm 22.6$, ウで $23.1 \pm 24.3$, $8.4 \pm 13.7,0.2 \pm 0.8$, エで $44.8 \pm 28.1,41.2 \pm 28.5$, $26.1 \pm 21.2$ ，才で $5.2 \pm 12.9 ， 2.2 \pm 6.8 ， 0.1 \pm 0.5$ であ った（表15）。

表14 臨床的歯冠表面積に対するア行音発音時に露 出した上顎前雨の表面積の比

\begin{tabular}{l|r|r|r}
\hline \hline & \multicolumn{1}{|c|}{1} & \multicolumn{1}{c}{2} & \multicolumn{1}{c}{$\underline{3}$} \\
\hline ア & $35.1 \pm 21.4$ & $12.6 \pm 17.1$ & $3.4 \pm 8.2$ \\
イ & $48.7 \pm 23.9$ & $32.5 \pm 25.2$ & $12.9 \pm 19.1$ \\
ウ & $11.2 \pm 12.8$ & $0.7 \pm 3.1$ & $0.0 \pm 0.0$ \\
エ & $35.4 \pm 22.9$ & $15.8 \pm 20.2$ & $4.9 \pm 13.7$ \\
オ & $7.0 \pm 11.5$ & $0.0 \pm 1.2$ & $0.0 \pm 0.0$ \\
\hline
\end{tabular}

表15 臨床的茵冠表面積に対するア行音発音時に露 出した下顎前粤の表面積の比

\begin{tabular}{c|r|r|r}
\hline \hline & $\overline{1}$ & \multicolumn{1}{c}{$\bar{c}$} & \multicolumn{1}{c}{$\overline{3}$} \\
\hline$ア$ & $32.5 \pm 25.5$ & $29.6 \pm 26.1$ & $18.4 \pm 20.3$ \\
$イ$ & $72.9 \pm 22.8$ & $69.7 \pm 23.3$ & $51.3 \pm 22.6$ \\
$ウ$ & $23.1 \pm 24.3$ & $8.4 \pm 13.7$ & $0.2 \pm 0.8$ \\
$エ$ & $44.8 \pm 28.1$ & $41.2 \pm 28.5$ & $26.1 \pm 21.2$ \\
オ & $5.2 \pm 12.9$ & $2.2 \pm 6.8$ & $0.1 \pm 0.5$ \\
\hline
\end{tabular}

10. ア行音発音時に露出した上顎前蒾および下顎前歯 の表面積に関する崡牙間の比

上顎についてア行音発音時の中切歯の露出度を 1 とし て側切歯, 犬歯の此率を求めた。アでは $1: 2: 3=1$ $: 0.2: 0.1$ イイでは $1: 0.4: 0.1$, ウでは $1: 0.0$ :

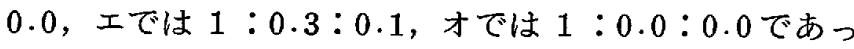
た（表16）。
つぎに，下顎についてア行音発音時の中切歯の露出度 を 1 として, 側切歯, 犬歯の比率を求めた. アでは $\overline{1}$ : $\overline{2}: \overline{3}=1: 0.9: 0.6$, イでは $1: 1.0: 0.8$, ウでは $1: 0.4: 0.0$, エでは $1: 0.9: 0.6$, オでは $1: 0.5 ：$ 0.0であった（表17）.

表16 ア行音発音時に露出した上顎前米の表面積に 関する雬牙間の比

\begin{tabular}{c|ccccc}
\hline \hline & $\underline{1}$ & $:$ & $\underline{2}$ & $:$ & $\underline{3}$ \\
\hline ア & 1 & $:$ & 0.2 & $:$ & 0.1 \\
イ & 1 & $:$ & 0.4 & $:$ & 0.1 \\
ウ & 1 & $:$ & 0.0 & $:$ & 0.0 \\
エ & 1 & $:$ & 0.3 & $:$ & 0.1 \\
オ & 1 & $:$ & 0.0 & $:$ & 0.0 \\
\hline
\end{tabular}

表17 ア行音発音時に露出した下顎前歯の表面積に 関する雬牙間の比

\begin{tabular}{c|ccccc}
\hline \hline & $\overline{1}$ & $:$ & $\overline{2}$ & $:$ & $\overline{3}$ \\
\hline ア & 1 & $:$ & 0.9 & $:$ & 0.6 \\
イ & 1 & $:$ & 1.0 & $:$ & 0.8 \\
ウ & 1 & $:$ & 0.4 & $:$ & 0.0 \\
エ & 1 & $:$ & 0.9 & $:$ & 0.6 \\
オ & 1 & $:$ & 0.5 & $:$ & 0.0 \\
\hline
\end{tabular}

11.ア行音発音時に露出した上顎前歯表面積に対する 下顎前歯の表面積の比

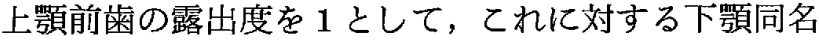
柬の露出度を比較的簡単な比として表した。中切歯，側 切歯，犬霜でそれぞれ，アでは $1: 0.4,1: 1.9,1$ ： 5.1 , イで中切霜が $1: 0.7$, 側切霜が $1: 1.8$, 犬歯が $1: 3.9$, ウで中切霖が $1: 1.0$, 側切霜が $1: 10.7$, 工 で中切霜が $1: 0.6$, 側切菌が $1: 2.1$, 犬霆が $1: 5.0$,

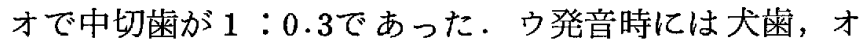
発音時には側切歯および犬歯はほとんど露出していなか った（表18）.

表18ア行音発音時に露出した上顎前歯の表面積に 対する下顎前䨑の表面積の比

\begin{tabular}{|c|c|c|c|}
\hline & 中 切歯 & 側 切 霜 & 犬 \\
\hline$>$ & $1: 0.4$ & $1: 1.9$ & $1: 5.1$ \\
\hline 1 & $1: 0.7$ & $1: 1.8$ & $1: 3.9$ \\
\hline ウ & $1: 1.0$ & $1: 10.7$ & $0: 0.0$ \\
\hline$x$ & $1: 0.6$ & $1: 2.1$ & $1: 5.0$ \\
\hline 才 & $1: 0.3$ & $0: 0.0$ & $0: 0.0$ \\
\hline
\end{tabular}




\section{考察}

補経の主な目的は，咀嚼および発音機能の回復ならび に審美性の回復である，今日の社会においては, 前歯部 の歯質崩壊あるいは歯の品失を放置したままでいること はほとんどない，そこでそれらの補経に祭しては個性的 形態に回復することが必要となってきた．審美性の概念 は時代とともに変化してきたし, 場所によっても異なる が，現在では患者の希望を十分入れながら，可能な限り 歯質あるいは歯牙喪失前の状態に回復することが最良の 方法と考えられている。しかし，欠損歯が多い症例にお いては, 前歯部䨑列再構成のための何らかの基準が必要 であり，そのために数多くの方法が報告されている.

審美の概念を現在のように体系づけ，補緅臨床に導入 したのは Frush と Fisher (1955〜1959)6ー10)であろ う. 彼らは義柬の人工歯を排列する際に, S.P.A. factor, すなわち性的特徵 (Sex), 性格的特徴 (Personality)，年秢的特徽（Age）を表現すべきであるとし， Dentogenicsという表現を用いて自然感あふれる義蒾 の作製法について報告している。 また, Dentsuply 社 は, 義蒾の最終目標を E.P.F. factor, すなわち審美 (Esthetic), 発音 (Phonetic), 機能 (Function) の 3 要素であるとの概念に従って人工柬を選択し, 義歯を作 製すべきであると提唱している。

当然のととながら前霜を含む䨑冠補経を行うにあたっ ても, 材料学的, 色彩学的, 形態学的考慮がなされてお り，臨床への具体的応用法が紹介されている401.

わが国においても，個性正常咬合を有する被験者を対

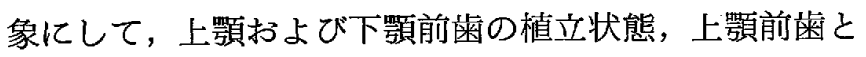
下顎前菌の対向関係, さらに上顎前菌と顔面各部との形 態的類似性に関する数多くの研究報告がある.とれらの ほとんどは, 顔面写真あるいは模型上での顔面形態およ び上下顎歯列弓の形態的観察であり，この意味では解剖 学的観察あるいは静的審美に関する検討ともいうことが できよう.

これらの静的審美に関する検討が必要なことは当然の ことではあるが, 害際の審美の立場からすると，てれだ けでは不十分である，すなわち，雨は口腔の所定の位置 に植立し，動くととはないが，その外側にある口唇が機 能に応じて動くことにより㐘の見え具合いは隠見自在と なり，顔面の表情にとっては欠かすととができない美的 要因である．

そこで，著者は発音機能に着目して，ア行音発音時の 上下顎前蒾の露出度について検討した。

1. 安静時における上下口唇接合線之上顎中切歯切縁
との関係

上顎中切歯切緣の位置は, 咬合平面の前方決定要素で あり，総義歯においては人工歯排列の起始点として大切 であるだけでなく，てれが上下口唇接合線と非常に近接 しているために，安静時および機能時における両者の位 置的関係を知ることは, 補緅臨床上非常に興味あること である。

機能時における上下口唇接合線と上顎中切歯切縁の位 置的関係は，審美性ならびに発音の立場から従来より検 討されている. 顔面表情のうち, やさしさ, 健康, 友好 などを表現するうえで最も重要なすのの1つは微笑であ り，微笑時の口唇と前雨雪列の位置的関係を知るととは 審美的に補緅を行う際に考慮すべき事項である．そこで 微笑時における両者の位置的関係について, Anthony ら (1984) ${ }^{33}$ ， 木村ら $(1985)^{34}$ らが検討している。ま た，発音に関しては，Pound $(1966,1976)^{35,36) は, ~}$ FあるいはV音発音時には上顎中切霜切縁は下口唇の赤 唇・紅唇移行部に接触すべきであるとの考えから, 上頢 前曾の人工歯排列の適否の判定に利用する方法を紹介し た。

このように上顎前柬と口唇との位置的関係は機能と密 接な関係があるが，上顎中切歯切縁は咬合平面の前方決 定要素であり，安静時の上下口唇接合線の位置と近接し ているため，安静時にも重要である。

Gysi は上下口唇接合線より $2 \mathrm{~mm}$ 下に咬合平面を決 定して上顎中切雪をその位置に排列する方法を提唱し た。また，坪根は咬合平面を上下口唇接合線に一致させ て決定し，それより $2 \mathrm{~mm}$ 下に上顎中切歯切縁がくるよ うに排列することを提唱した41，総義歯の人工歯排列 にはどちらかの方法が採用されているのが現状である． いずれにしても，上下口唇接合線よりも約 $2 \mathrm{~mm}$ 下に上 㖽中切歯切縁があることが審美的であるという立場に立 っているといえよう．そこで著者は，安静時の上下口唇 接合線に対する上顎中切柬切縁の位置的関係を調べた . その結果, 平均的には上顎中切夹切縁のほうが約 $2 \mathrm{~mm}$ 下にあるととが確認できたが，上顎中切崡切縁が上下口 唇接合線より上にある例が $4 \%$ 上り，その最大值は 2.2 $\mathrm{mm}$, また, 上顎中切菌切縁が上下口唇接合線より下に ある例は $86 \%$ であり，その最大值は $5.8 \mathrm{~mm}$ とバラッキ が大きいことがわかった。

光井ら (1951 $)^{19}$ は, 日本人男性を対象にして安静時 における上唇下縁に対する上顎中切柬切縁の位置関係を 計測し, 後者が $2.4 \pm 0.01 \mathrm{~mm}$ 下方にあったと報告して いる. 著者は安静時における上下口唇接合線を基準にし 
たとてろ上顎中切歯切縁が $2.0 \pm 1.6 \mathrm{~mm}$ 下方にあるとい う結果を得た。表現は異なるものの，両者には実質的な 差はほとんどないために計測值は近似していた。

そてで, Gysi 法あるいは坪根法のように上下口唇接 合線より $2 \mathrm{~mm}$ 下に上倣中切歯切縁の位置を決定するこ とは平均的には正しいことが確認されたが，個人差が大 きいために個性にあった位置づけが必要であろう。

2.ア行音発音時に露出した上下額前蒾の垂直的長さ 日本語の特徵は母音にあるといっても過言ではない。 母音単独で発音されることはもちろんであるが，子音は 子音だけで発音されることはほとんどなく，先行子音と 後続母音とが組み合わさってはじめて言語となるからで ある．乙の母音は共鳴腔である口腔の形態を変化させる ことによって特徴づけられるもので，アを基準にして口 角を側方に牽引するととによって漸次エ，イが発音さ れ，またアを基準にして口唇を狭め乫出させることによ り漸次オ, ウが発音される，そてで日本語母音の基本音 はア，イ，ウの 3 音であり，その他は乙れらの中間音と しての位置づけがなされている。

つまり母音の最基本音はアと考えてよいであろう．そ てでア発音時に露出した中切歯の長さに着目して，てれ と咬頭嵌合位において口唇が緊張していないときの上下 口唇接合線汶対する上顎中切雨切縁の位置的関係との相 関性の検討を行った，発音時における審美を観察するに あたっては, 日常会話時の様子を対象とすべきである が, 口唇を中心とした顔面形態が発音と共に変化するた め, 特定の発音時の様子をとらえることが困難である. そこで今回は, ア行音の各音を長めに発音させて, 口唇 の動きがほとんどなくなったときの状態を対象とした。 その結果, 相関係数は0.69で高度に有意の相関関係が認 められ, 非機能時の上顎中切歯切縁の位置が発音時の歯 の見え具合いに大きく影響することが確認された。この てとは前歯部補経を行うにあたっては, 静的審美の立場 からも，また動態審美の立場からも，上顎中切茵切縁の 位置決定が最も重要であるととを示唆しているものと思 われる。

さて, 前述したように母音を特徽づけるのは, 口腔の 容積であり，アを基準にして口角を側方に旁引儿ながら 口腔容積を減少させるとエおよびイが発音される，ア， 1 , 工発音時に露出した上頢前歯の垂直的長さは, 中切 歯, 側切歯, 犬歯のすべての霜で, 口角を最も側方に旁 引した状態で発音されるイが最大で, エとアはほほ同程 度であった. 下顎前歯では, 中切歯, 側切歯, 犬函とも イが最大で，ついでェ，アであった。また，ウおよびオ
はアを基準にして口唇を突出することにより発音され る.ウおよびオ発音時には側切歯, 犬歯はほとんど露出 していなかった．中切歯においてオよりもウの方が多く 露出していたのは, ウを発音するためには才発音時より も, 口唇を突出するとともに開口量を小さくしなければ ならないためであろう。

ア，イ，工発音時に露出した垂直的長さは上顎では中 切畨, 側切歯, 犬歯において, アでそれぞれ $3.8 \pm 2.3$,

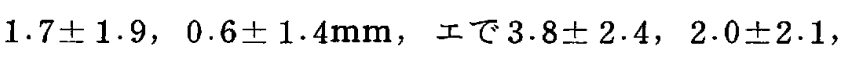
$0.7 \pm 1.7 \mathrm{~mm}$ でほぼ同様の順向であり，中切歯を基準に して側切蒾および犬歯の発音時における垂直的長さにつ いて比較すると，それぞれ $1: 0.4: 0.2,1: 0.5: 0.2$ であった. イでは中切歯, 側切䨑, 犬雪はそれぞれ 5.3 $\pm 2.5,3.5 \pm 2.1,1.8 \pm 2.3 \mathrm{~mm}$ で, その比は $1: 0.7$ : 0.3であった，すなわち，ア，イ，エとも後方茵ほど露 出する量は漸次減少していた。下顎では中切歯, 側切 歯, 犬歯において，アでそれぞれ $2.6 \pm 2.0 ， 2.6 \pm 2.2$,

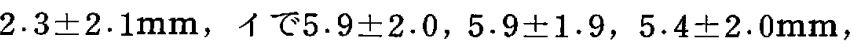

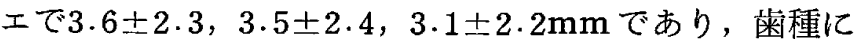
より長さに差はあるものの，中切歯を基準にした比にな おすと,ア，イ，エとも全て $1: 1: 0.9$ であり, 中切 㐘, 側切歯, 犬歯はほぼ同程度露出していることがわか った。すなわち，ア，イ，工発音時においては，下顎中 切崡および側切曾の切縁と犬歯尖頂は，ほぼ同じ長さだ け露出して，下口唇とほぼ平行な曲線となることが明ら かとなった。

ウ，才に関しては，上顎ではウ発音時の側切歯で92 $\%$ ，犬歯で100\%，才発音時の側切歯で $98 \%$ ， 犬歯で100 $\%$ 之露出しない例が非常に多かった。下顎では，才発音 時の中切歯, 側切歯, 犬雪でそれぞれ $82,84,98 \%$, ウ 発音時の犬歯で $94 \%$ 之露出しない例が多かった。

また，ア行音発音時に露出した上顎前歯の垂直的長さ に対する下顎前崡の垂直的長さの比率を算出したとと ろ,アおよびオ発音時の中切歯でそれぞれ $1: 0.7,1$ $: 0.6$ と下顎前歯の露出度が少なく, イ, ウ, 工発音時 の中切菌でそれぞれ $1: 1.1,1: 1.3,1: 0.9$ とほぼ 同程度の露出度であった，側切歯, 犬歯に関しては下顎 の露出度の方がはるかに大であった。

従来, 前菌部補経において形態的, 機能的考慮がなさ れていたのは，ほとんどが上顎であった。しかし，発音 学的立場汃 万, Pound $\left.(1966,1976)^{35}, 36\right)$, 山縣 (19 $76,1982)^{37,38)}$, Silverman $(1962)^{42)}$, 桃谷 (1987) 43) らが上顎はもちろんであるが，下顎前歯に対しても 十分な配慮をしなければ満足のいく発音機能の回復がで 
きないととがあるととを指摘し，Pound， Silverman らは発音を障害しない前菌の補緅法について言及した。

また審美的考慮は，一見して目につきやすい上顎が対

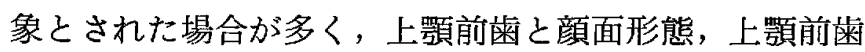
の植立状態，上䫈前歯の臨床的形態に関する研究報告は 多くみられる。しかし，上顎に被蓋されて目立たない存 在である下顎前菌に対しては関心が浅く，下顎前歯切縁

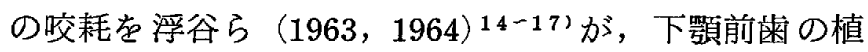
立状熊に 関して㗽庭ら (1958) 11-13), 臨床的形態変化 について松本 $(1965)^{23)}$ ，佐藤 $(1987)^{25)}$ の研究なぞが 見られる程度である。

ア行音発音時には上顎の雬のうち，個人差はあるもの の, 中切䨑はほとんぞの場合が露出するが，側切歯ある いは犬歯は露出しないととがあるととが明らかとなっ た、これは特にウおよびオ発音時に顕著であった．ま た，下顎の歯は上澒よりも露出する傾向が大であること が多いうえ, 音の種類によって露出度が変化に富むと

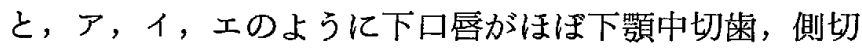
歯の切縁抢よび犬曾の尖頂を結んだ線と平行になること などが明らかとなった。てれらの特徽は人工歯排列の適 否の判定に大いに参考とすべきであり，発音の立場から 審美を考えるためには，上顎はもちろんであるがそれ以 上に下顎への配慮も必要であることが明白となった。

3. ア行音発音時に露出した上下顎前歯の表面積につ いて

従来の審美性に関する研究は柬冠長, 歯冠幅, 粜冠軸 などが対象とされることが多く，そのため点あるいは線 を計測したのが主とんどであった。しかし，補緅学にお ける審美は顔面および歯列弓の形態, 歯牙の植立状態に ついて検討する場合が多く，そのためには，点や線を計 測するだけでなく，面として検討する方が合理的である と佐藤 $(1981)^{24}$ 'は述べている.

著者はア行音を対象にして発音時の上下枵前歯の露出 度を検討し，発音という機能を通して動態審美を明らか にするてとを試みた。そこで，まず，前項までで歯冠中 央部の垂直的長さに関する検討を行ってきた。しかし， 特に動態番美は口唇と歯牙との関係を 3 次元的倍調查す ることが理想的であり，歯冠中央部のみを対象とした垂 直的長さの観察だけでは不十分であると考えた。をて で, 佐藤の方法を参考にして, 正中方向から撮影した写 真上で面積を計測し，ア行音発音時に露出した歯牙の状 態を面積の立場から検討を加えた。

ア行音発音時の上顎前蒾の露出度を菌冠中央部の垂 直的長さで計測し，中切迷の長さを 1 としたときの側
切䨑, 犬雪の割合を求めると, イで $1: 0.7: 0.3$ であ り, 側切曾および犬霜が露出する程度はア行音中最も大 であり，ついでアおよびェでそれぞれ $1: 0.4: 0.2$, $1 ： 0.5: 0.2$ でほほ近似した比率であることが確認でき た. 堀 $(1979)^{39)}$ は正面観における上颓前菌の横径の割 合は 1 ： $\underline{2}: \underline{3}=8: 6: 5$ であると報告しており，て の比率とア行音発音時に露出した上顎前䨑の垂直的長さ の比との積を求め, ア行音発音時に露出する歯冠表面積 比の推定值とした. その結果, アでは中切匊で 8 , 側切 茵で2.4, 犬歯で1.0，イではそれぞれ $8 ， 4.2,1.5$, 工 では $8 ， 3.0 ， 1.0$ となった.乙れらの值から中切曾を 1 として側切歯，犬歯の此を算出すると，アでは $11: 2$ ： $\underline{3}=1: 0.3: 0.1$, イでは $1: 0.5: 0.2$, エでは $1: 0.4$ :0.1となる. 本研究で計測された表面積は，アで 1 : $0.2: 0.1$ ，イで $1: 0.4: 0.1$, エで $1: 0.3: 0.1$ であ り,ア，イ，エで特に側切雷の比において推定值より実 測值の方が低い值であった。乙れは，てれらの音を発音 するために側切雨の遠心で口唇をあまり挙上しなくても 済むためであろう。

ウおよびオに関してはほとんど露出していなかったの で比較検討できなかった。

また，下顎に扔いても上顎と同様にして，ア行音発音 時の下顎前雨の露出度を菌冠中央部の垂直的長さで計測 し, 中切蒾の長さを 1 としたときの側切霜, 犬歯の割合

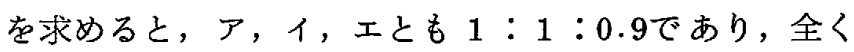
同じ比率であることが確認できた。佐藤 $(1987)^{25}$ ) は正 面観における下顎前歯の横径の割合はほぼ $\overline{1}: \overline{2}: \overline{3}=$ 1：1：1であると報告して抢り，ての比率とア行音発 音時に露出した下顎前歯の垂直的長さの比との積から， ア行音発音時に露出する菌冠表面積比の推定値を算出 し, てれらの值から中切歯を 1 として側切歯, 犬歯の比 を算出すると，ア，イ，エのすべてで $\overline{1}: \overline{2}: \overline{3}=1 ：$ $1: 0.9$ となった. 本研究で計測された表面積の比は, アで $1: 0.9: 0.6$, イで $1: 1.0: 0.8$, エで $1: 0.9:$ 0.6 あったた.すなわち,ア,イ, エとも, 側切崡では 推定値と実測值との差はないととがわかった。しかし， 犬歯に扔いては，イに扔いては両者の間にほとんど差は ないものの，ア，エではかなりの差があったととから， イにおいては犬歯部まで十分に口角が率引されて発音が 行われるので審美的な考慮が特に必要であることが示唆 された。

ウおよびオに関してはほとんど露出していなかったの で比較検討できなかった。 
結論

前棶部補綴にあたっては，上顎舌面および下顎切縁の 位置を顎運動に調和するよう形成すること，上顎前蒾の 長さ上下顎前歯の被蓋度を発音に障害がないように形成 することなどに注意しなければならないが，さらに前㐘 の審美についても考慮する必要がある，そてで安静時お よび機能時の顔面の特徵を明らかにするために，20歳代 の男性50名を対象にして, 安静時における上類前歯切縁 と上下口唇接合線との位置的関係を計測し，またア行音 発音時の上下顎前歯の見え具合いについて検討した。 そ の結果は以下のと抢りである.

1. 咬頭嵌合位で口唇が緊張していないとき，上顎中 切菌切縁は上下口唇接合線より $2.0 \pm 1.6 \mathrm{~mm}$ 下にあっ た．その範囲は前者が後者より $5.8 \mathrm{~mm}$ 下方から $2.2 \mathrm{~mm}$ 上方までであった。

2. 上筫前歯の臨床的歯冠長は, 中切歯で $10.8 \pm 1.0$ $\mathrm{mm}$, 側切菌で $9.2 \pm 0.9 \mathrm{~mm}$, 犬歯で $10.2 \pm 1.1 \mathrm{~mm}$ であ った. 下顎では中切歯で $8.6 \pm 1.0 \mathrm{~mm}$, 側切歯で $9.0 \pm$ $1.0 \mathrm{~mm}$, 犬歯で $10.5 \pm 1.2 \mathrm{~mm}$ であった.

3. ア行音発音時に露出した上頻前歯の長さは, 中切 歯および側切歯でイ>エ气ア>ウ>オであり, 犬歯では イ>ェうア>ウニオであった. 下顎では全ての歯でィ> エ>ア>ウ>オであった.

4. 臨床的歯冠長に対するア行音発音時に露出した上 㖽前菊の垂直的長さの比は, 中切雨のイで $0.5, ア, エ$

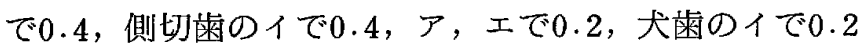
であり，他は 0.1 以下であった。

5.ア行音発音時に露出した上罰前歯の垂直的長さ の比はアで $1: \underline{2}: \underline{3}=1: 0.4: 0.2$, イで $1: 0.7:$
0.3 , ウで $1: 0.1: 0.0$, エで $1: 0.5: 0.2$, オで $1:$ $0.0: 0.0$ であった.

6. 臨床的歯冠長に対するア行音発音時に露出した下 顎前歯の垂直長さの比は, 中切蒾のイ, エ,ア，ウでそ れぞれ0.7, 0.4, 0.3,0.2, 側切歯のイ, エ, アでそれ ぞれ0.7,0.4，0.3, 犬䍘のイ, エ, アでそれぞれ 0.5 , $0.3 ， 0.2$ であり，他は0.1以下であった.

7. ア行音発音時に露出した下顎前歯の垂直長さの比 はア, イ, エで $1: \overline{2}: \overline{3}=1: 1.0: 0.9$, ウで $1:$ $0.5: 0.1$, オで $1: 0.6: 0.0$ であった.

8. 前頭面に投影した臨床的柬冠表面積は，上䫑では 中切歯で79. $4 \pm 9.8 \mathrm{~mm}^{2}$, 側切歯で $47.6 \pm 6.4 \mathrm{~mm}^{2}$, 犬 柬で $43.4 \pm 6.9 \mathrm{~mm}^{2}$ であった。 下顎では中切歯で $38.2 \pm$ $5.7 \mathrm{~mm}^{2}$, 側切歯で $40.0 \pm 5.7 \mathrm{~mm}^{2}$, 犬歯で $42.6 \pm 6.9$ $\mathrm{mm}^{2}$ であった。

9. ア行音発音時に露出した上罰前歯の表面積の比 は, アで $1: \underline{2}: \underline{3}=1: 0.2: 0.1$ イで $1: 0.4:$ 0.1 , ウで $1: 0.0: 0.0$, エで $1: 0.3: 0.1$, オで $1:$ $0.0: 0.0$ であった.

10. ア行音発音時に露出した下䫟前雪の表面積の比 は, アで $1: \overline{2}: \overline{3}=1: 0.9: 0.6$ ，イで $1: 1.0:$ 0.8 , ウで $1: 0.4: 0.0$, エで $1: 0.9: 0.6$, オで $1:$ $0.5: 0.0$ であった.

稿を終わるにあたり，終始御想篤なる御指導と御校閲 を睗った恩師豊田静大教授に対し蚛心より謝意を捧げる とともに，本研究に御協力いただきました三宅茂樹講師 ほか本学補綴学教室員諸氏ならびに本研究に快く協力し て頂いた被験者の方々に厚く御礼申し上げます。

\section{引用 文 献}

1) 中村俊一：前歯. 而至, 東京, 1960 .

2 ）西浦 恂訳：Esthetics 審美補緅.モリタ, 大阪，1975，64一69.

3 ) Williams, J.L. : The esthetic and anatomical basis of dental prosthesis. Dental Cosmos 53 : 1,1911 .

4 ) Williams, J.L. : A new classification of human tooth forms with special reference to a new system of artificial teeth. Dental Cosmos 56:627-628, 1914.

5) Stein, M.R. : Williams' classification of anterior tooth forms. J. Amer. Dent. Assoc. $23: 1512$ $-1518,1936$.

6) Frush, J.P. and Fisher, R.D. : Introduction to dentogenic restorations. J. Prosthet. Dent. $5: 586-595,1955$.

7) Frush, J.P. and Fisher, R.D. : How dentogenic restorations interpret the sex factor. $J$. 
Prosthet. Dent. $6: 160-172,1956$.

8) Frush, J.P. and Fisher, R.D. : How dentogenics interprets the personality factor. $J$. Prosthet. Dent. $6: 441-449,1956$.

9) Frush, J.P. and Fisher, R.D. : The age factor in dentogenics. J. Prosthet. Dent. $7: 5-13$, 1957 .

10) Frush, J.P. and Fisher, R.D. : The dynesthetic interpretation of the dentogenic concept. $J$. Prosthet. Dent. $8: 558-581,1958$.

11）经庭格太郎・羽賀通夫・浮谷 実・江崎梅太郎・橋本 脩：前函排列の研究（第 1 報）. 補経誌 2 : 135一 138,1958 .

12）苳庭格太郎・羽賀通夫・浮谷 実・江崎梅太郎・橋本 脩 : 前歯排列の研究（第 2 報）正常群の霜冠傾斜角 度. 補緅誌 $2: 141-144,1958$.

13）这庭格太郎・羽賀通夫・浮谷 実・江崎梅太郎・橋本 脩：前爾排列の研究（第 3 報）正常群の前歯菌列彎 曲. 補緅誌 $2: 145-148,1958$.

14）浮谷 実・羽賀通夫・片岡保夫・腰原 好・太田是男・長谷川 汎・清水 忠・広田 稔：前菌の晈耗 そ の 1 上龥中切菌. 茵科学報 $63: 670-673,1963$.

15）浮谷 実・羽賀通夫・片岡保夫・腰原 好・太田是男・長谷川 汎・清水 忠・広田 稔：前歯の咬耗 そ の 2 上颉側切歯. 蒾科学報 $64: 349-353,1964$.

16）浮谷 実・羽賀通夫・片岡保夫 ·腰原 好・太田是男・清水 忠・岩田春子・広田 稔・長谷川 汎：前茵 の咬耗 その 3 上顎犬蒾. 歯科学報 $64: 742-746,1964$.

17）広田 稳・浮谷 実・腰原 好・太田是男・清水 忠・岩田春子・羽賀通夫：前霜排列の研究 下顎犬蒾咬 耗形態について〔会]. 歯科学報 $64: 782,1964$.

18）光井敏郎・坖谷博之・本澤誠一：補経学上から観た顔面並びに顎の研究 その 1 邦人顔面計測（成人）. 歯科医学 $14: 318-328,1951$.

19）光井敏郎・金谷博之・本澤誠一：補綴学上から観た顔面並びに顎の研究 その 2 歯牙と口唇との関係. 歯 科医学 $14: 329-333,1951$.

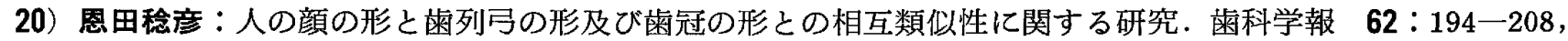
1962 .

21）高橋 衛：日本人成年男子の顔面形態と前柬部菊冠形態との関連性に関する研究. 補経誌 $11: 39$ 一2, 1967.

22) Lombardi, R.E. : The principles of visual perception and their clinical application to denture esthetics. J. Prosthet. Dent. $29: 358-382,1973$.

23）松本直之：増歯的にみた臨床的歯冠形態に関する研究. 口病誌 $32: 108-136,1965$.

24）佐藤博信：上顎前䨑部正面形態の増齢的変化. 九州歯会誌 $34: 489-511,1981$.

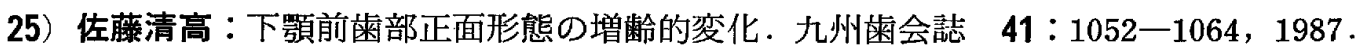

26) Sproull, R.C. : Color matching in dentistry. Part 3 . Color control. J. Prosthet. Dent. $31: 146$ $-154,1973$.

27）河辺重勝：日本人歯牙色調 殊に歯牙色調の変差に関する研究，第 1 報 大数例における日本人上顎中切歯 色調の年齢的性格の解析について. 口病誌 $26: 2079-2094,1959$.

28）河辺重勝：日本人歯牙色調 殊に歯牙色調の変差に関する研究，第 2 報 日本人上顎中切蒾の色調の変動分 散より晃たる年齢的性格について. 口病誌 $26: 2095-2100 ， 1959$.

29）河辺重勝：日本人歯牙色調 殊に歯牙色調の変差に関する研究，第 3 報 日本人上顎中切䨑の色調の左右差 の検討について．口病誌 $26: 2101-2107,1959$.

30) 土屋 潔：前画の色彩学的研究. 歯科学報 $73: 87-120,1973$.

31）上原秀樹：上下顎前歯の色彩学的研究. 九州歯会誌 $34: 465-488,1981$. 
32) Matthews, T.G. : The anatomy of a smile. J. Prosthet. Dent. 39:128-134, 1978.

33) Anthony, H.L., Gary, D.M. and Josephine, G.P. : Some esthetic factors in a smile. $J$. Prosthet. Dent. $51: 24-28,1984$.

34）木村博光・小長井文夫・羽田皓而・林 亨・柴田和宏・西島奉一・千葉栄一・稲葉 繁・横塚繁雄：粜之表 情に関する研究一スマイル時の雬牙と口唇の位置的関係一。粜学 $72: 1251-1255,1985$.

35) Pound, E. : The mandibular movements of speech and their seven related values. J. Prosthet. Dent. $16: 835-843,1966$.

36) Pound,E. : Controlling anomalies of vertical dimension and speech. J. Prosthet. Dent. 36 : $124-135,1976$.

37）山縣健佑：発音機能における前霜の役割．歯界展望 $48: 73-83 ， 1976$.

38）山縣健佑：人工蒾排列之発音. 歯科ジャ一ナル $15: 131-137 ， 1982$.

39）堀 孝良：上顎前菊部の柬冠幅抢よび植立状態と顔面各部の横径との関係について. 九州雨会誌 $33: 1-$ 15,1979 .

40) Goldstein, R.E. : Esthetics in Dentistry. J.B. Lippincott Comp., Philadelphia, 1976.

41）坪根政治・豊田静夫：総義歯臨床形態学. 医歯薬出版, 東京, $1978 ， 371-414$.

42) Silverman, M.M. : Occlusion in prosthetics and in the natural dentition. Mutual Publishing Company, Washington, 1962.

43）桃谷泰藏：下顎前歯部の排列位置の変化が発音に及ぼす影響. 九州米会誌 $41 ： 1171-1186 ， 1987$. 